\title{
XX. On a kind of radioactivity imparted to certain salts by cathode rays
}

\section{J.C. McLennan Ph.D.}

To cite this article: J.C. McLennan Ph.D. (1902) XX. On a kind of radioactivity imparted to certain salts by cathode rays, Philosophical Magazine Series 6, 3:14, 195-203, DOI: 10.1080/14786440209462754

To link to this article: http://dx.doi.org/10.1080/14786440209462754

册 Published online: 08 Jun 2010.

Submit your article to this journal

Џll Article views: 4

Q View related articles $\square$

4 Citing articles: 10 View citing articles 5 
It is perhaps worth noticing that if the dotted part of the $\mathrm{Fe}-\mathrm{Cu}$ curve (fig. 5) (which is marked $\mathrm{HI}$ and represents the first few points obtained by heating a fresh couple in hydrogen) be produced, it cuts the upper and "constant" portion of the curve at a temperature just below $800^{\circ}$, the temperature of the resistance-changes in iron.

In conclusion I wish to express my best thanks to Professor Callendar, F.R.S., for constant help and advice during this research, which was undertaken at his suggestion.

My thanks are also due to Mr. G. M. Gibbins, of University College, for help during the first part of the thermoelectric measurements.

XX. On a kind of Radioactivity imparted to certain Salts

by Cathode Rays. By J. C. McLmnnan, Ph.D., Demonstrator in Physics, University of Toronto*.

\section{Introduction.}

T $\mathrm{T}$ has been shown by Curie $\dagger$ that every substance, placed 1 in the neighbourhood of radium, itself acquires a radioactivity which persists for many hours and even days after the removal of the radium. Curie $\ddagger$ has also obtained a similar but more feeble effect with the active preparation polonium.

Rutherford \&, too, has shown that thorium compounds under certain conditions possess the property of produoing temporary radioactivity in all solid substances in their neighbourhood.

Up to the present time we appear to have only two recorded cases of substances becoming radioactive by the action of cathode rays.

Hofmann and Strauss $\|$ observed that radioactive lead sulphate prepared from the minerals uranpecherz, bröggerite, cleveite, uranglimmer, and samarskite, after losing its activity through lapse of time, was again made radioactive by exposing it to cathode rays.

Villard I found that a small piece of bismuth which had been used as the anticathode of a discharge-tube produced a

* Communicated by Prof. J. J. Thomson.

$\uparrow$ Rapports présentés au Congrès International de Physique, Paria, tome iii. p. $108(1900)$.

$\mp$ Curie, Comptes Rendus, t. cxxix. p. 714, Nov. 1899.

$\$$ Rutherford, Phil. Mag. vol. xlix. p. 161 (1900).

If Chem. Ber. xxxiv. pp. 8-11\&907-13; Beibl. xxv. pp. $317 \& 633$ (1901).

If Villard, Sociéte de Physique, juillet 1900.

$$
\mathrm{O} 2
$$


faint impression on a photographic plate. The action was very weak, and an exposure of eight days was necessary in order to make the effect visible.

This latter case appears to be the only example, hitherto recorded, of a substance normally inactive being made radioactive by exposing it to cathode rays.

In the following paper an account is given of an investigation in which several salts, showing no radioactivity as ordinarily prepared, were found to exhibit a very marked radioactivity on being gently heated after being exposed to cathode rays. With several of the salts a temperature of $100^{\circ} \mathrm{C}$. sufficed to exhibit the effect, though with still higher temperatures the radioactivity was more pronounced.

The radiation emitted by these salts was found to discharge positively charged bodies, but not those negatively electrified. In no case did it appear to impart a charge to an unelectrified body.

\section{Measuring Systemi.}

In order to study this radiation the system devised by C. T. R. Wilson* was used. A thin strip of brass, A (fig. 1), was suspended vertically in a small metallic box, $B$, by means of an insulating bead of sulphur, $C$. To this strip there was attached a gold leaf whose deflexions, observed with a micrometer microscope through a glass window in the apparatus, gave a measure of the potential of the brass strip.

The capacity of the whole measuring system was small, and at most did not exceed two centimetres.

A brass rod, D, which supported the measuring system passed through an ebonite plug, $\mathbf{E}$, and was connected to one of the terminals of a battery of small storage-cells, the other terminal of the battery being joined to the case of the electroscope.

A fine steel wire which was attached at its upper end to the rod, D, extended below the sulphur bead, and was there bent into a loop surrounding the brass strip. This steol wire could be readily drawn into contact with the strip, $A$, by means of a small magnet, and the measuring system by this operation was raised from time to time to any desired potential.

Besides having a small capacity, this measuring system possessed the advantage of being entirely free from leakage along its supports. In practice the conducting rod, D, was maintained, throughout any measurement, at the initial potential of the gold leaf, and consequently, when the latter

* Proc. Roy. Soc. vol. lxviii. p. 154. 
indicated any loss of charge, it was evident that such loss arose from a leakage through the gas surrounding the measuring system. Any conduction across the sulphur bead could only be in such a direction as to partially counteract the loss arising from leakage through the gas.

Fig. 1.

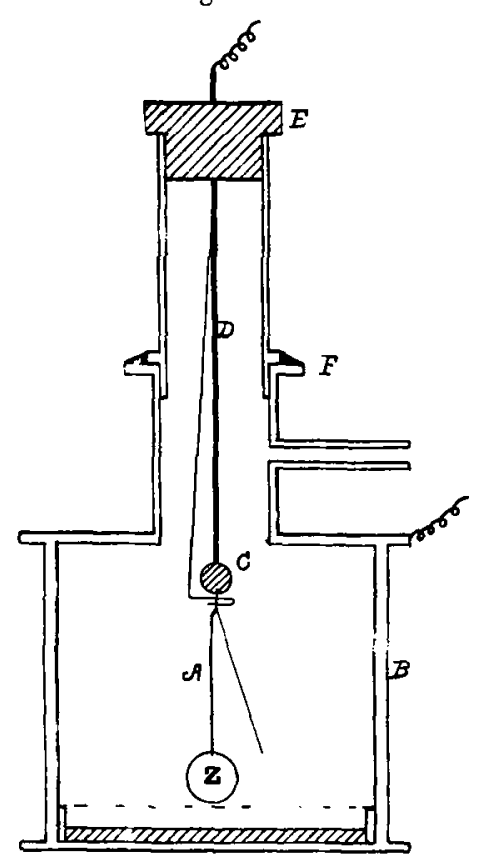

In order to get rid of disturbances of the gold leaf by aircurrents set up on applying heat to the base of the electroscope, the observations were made generally at a pressure of $15 \mathrm{mms}$. of mercury.

\section{Methods of making Salts Radioactive.}

In the initial stages of the investigation the salts to be tested for radioactivity were subjected to bombardment by cathode rays in a tube similar to that shown in fig. 2 (p. 198). This tube, while carrying but a single anode, was provided with a number of cathodes so that several salts could be simultaneously exposed.

The salts were generally exposed to the rays for half an hour, and from time to time during exposure were gently 
shaken in the tube so that fresh surfaces might be presented to the rays.

Fig. 2.

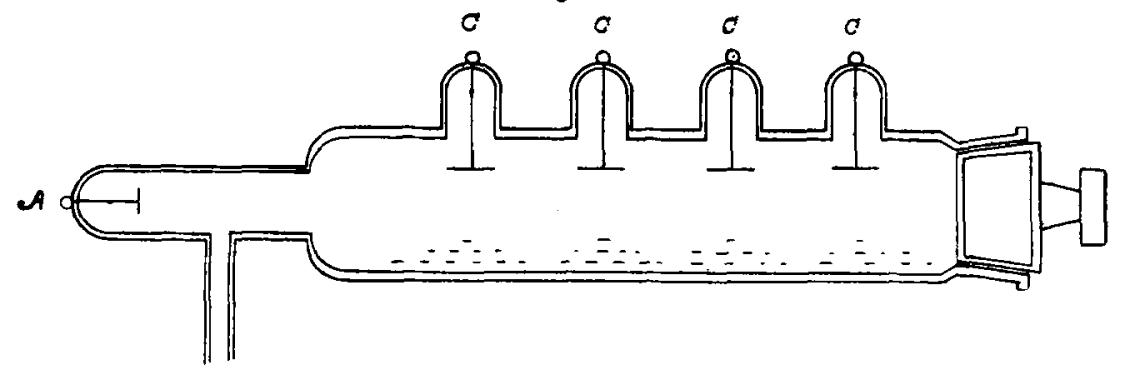

This method of exciting the salts was somewhat tedious, as it necessitated the exhaustion of the discharge-tube each time an exposure was made.

It was found, however, on trial that a radioactivity, similar and equal in intensity to that obtained with cathode rays, was imparted to the salts by simply exposing them in air at atmospheric pressure to the spark-discharge of an inductioncoil or Wimshurst machine. Short thick sparks were more effective in exciting radioactivity than long thin ones; and therefore, in most cases in which this method was adopled, a leyden-jar was inserted in parallel with the terminals of the induction-coil during the exposures.

Varions metals were used in turn as terminals for the coil, but no difference in their efficiency was observed.

In order to see whether the excited radioactivity was due to the presence of ultra-violet light in the spark-discharge, a quantity of one of the salts which could be made radioactive was placed in a shallow tray beneath the spark-gap and close to it. The sparks were made to pass between terminals of aluminium, and a thin quartz plate was placed between the salt and the spark-gap.

With this arrangement no radioactivity was imparted to the salt. On removing the quartz plate, however, so that nothing but air intervened between the salt and the sparkdischarge, the salt became radioactive with the usual exposure.

From this experiment it seemed clear that the observed radioactivity could not be due to the action of the ultraviolet light, but was in all probability excited by a peculiar kind of radiation shown by $\mathrm{E}$. Wiedemann * to be emitted hy the spark-discharge and called by him "Entladungstrahlen."

* Zeitschrift fuir Electrochemie, vol. ii. p. 159 (1895). 
IV. Radioactivity imparted to certain Salts.

When testing a salt for radioactivity the upper part of the electroscope which carried the measuring system was detached at $F$, and the salt placed in a thin layer on the base of the electroscope. The measuring system was then replaced and the apparatus made air-tight with sealing-wax. The air was then exhausted to a pressure of $15 \mathrm{~mm}$. of mercury, and the gold leaf was given a charge either positive or negative as desired. After this a Bunsen flame was applied to the base of the electroscope, and changes in the charge on the measuring system were observed by noting the motion of the gold leaf.

A list of the salts examined in this way, after bombardment by cathode rays, is given in Table 1 . With several no radioactivity was observed, but with others, such as the sulphites and sulphides of a number of the elements, a radiation was obtained which discharged the measuring system when positively electrified. In no case did this radiation discharge the gold leaf when negatively electrified. If the gold leaf was charged negatively, then on heating the salt the only effect was a slight disturbance of the leaf due, doubtless, to convection currents. If, however, the gold leaf was charged positively, no effect was observed until the salt reached a certain temperature; the leai then began to fall, and continued falling with a rapid and regular movement for a few minutes, and then stopped even though the beating continued.

TABle I.

\begin{tabular}{|c|c|c|c|c|}
\hline Substance. & & $\begin{array}{l}\text { Column I. } \\
\text { Gold leaf } \\
\text { positively } \\
\text { charged. }\end{array}$ & $\begin{array}{l}\text { Column II. } \\
\text { Gold leaf } \\
\text { negatively } \\
\text { charged. }\end{array}$ & $\begin{array}{l}\text { Column III. } \\
\text { Thermo- } \\
\text { luminescence. }\end{array}$ \\
\hline $\begin{array}{l}\text { Manganese Sulphate. } \\
\text { Zine } \\
\text { Lead } \\
\text { Beryllium ", } \\
\text { Calcium ", } \\
\text { Strontium ", } \\
\text { Barium ", } \\
\text { Potassium } \\
\text { Calcium Sulphide. } \\
\text { Strontium ", } \\
\text { Barium } \\
\text { Calcium Oride." } \\
\text { Calcium Chloride. } \\
\text { Barium " }\end{array}$ & $\begin{array}{l}\mathrm{MnSO}_{4} \\
\mathrm{ZnSO}_{4} \\
\mathrm{PbSO}_{4} \\
\mathrm{BeSO}_{4} \\
\mathrm{CaSO}_{4} \\
\mathrm{SrSO}_{4} \\
\mathrm{BaSO}_{4} \\
\mathrm{~K}_{2} \mathrm{SO}_{4} \\
\mathrm{CuS} \\
\mathrm{SrS} \\
\mathrm{BaS} \\
\mathrm{CaO} \\
\mathrm{CaCl}_{2} \\
\mathrm{BaCl}_{2}\end{array}$ & $\begin{array}{c}\text { No leak. } \\
\text { ", } \\
\text { Leak (small) } \\
\text { Leak. } \\
", \\
" \\
", \\
" \\
\text { No leak. } \\
", " \\
", "\end{array}$ & 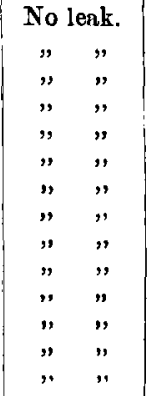 & $\begin{array}{l}\text { None obserred. } \\
\text { Faint white. } \\
\text { None observed. } \\
\text { None observed. } \\
\text { Yery faint. } \\
\text { Faint wbite. } \\
\text { Faint white. } \\
\text { None observed. } \\
\text { None observed. } \\
\text { None observed. } \\
\text { None obserred. } \\
\text { None observed. } \\
\text { Faint white. } \\
\text { Faint white. }\end{array}$ \\
\hline
\end{tabular}


The sulphates of calcium, strontium, barium, and potassium were found to differ but little in their radioactive powers, while the effect obtained with beryllium sulphate was quite small. In the case of the sulphides the radioactivity was found to be only about one-fifth that of the sulphates of the same elements.

It is of interest to note in this connexion that although calcium chloride could not be made radioactive, still calcium sulphate prepared from this salt became quite radioactive on being exposed to cathode rays.

All the salts examined rapidly lost their radioactivity on being heated. From three to five minutes' exposure in the electroscope to the flame of a Bunsen burner generally sufficed to drive off completely every trace of radioactivity.

The active salts also gradually lost their radioactivity with the lapse of time without being heated. With a specimen of calcium sulphate tested twenty hours after exposure to cathode rays, the leak obtained was faint though still quite marked.

In a series of comparative measurements with active calcium sulphate, in air at pressures varying from $480 \mathrm{mms}$. down to $1 \mathrm{~mm}$. of mercury, no difference either in the rate or the total amount of the positive leak was observed. At no pressure was any leak of the negative charge obtained, and the gold leaf, when initially unelectrified, did not acquire any charge from the radiation.

With the same salt (calcium sulphate) a magnetic field of 3000 C.G.S. units was found to slightly decrease the leak.

In order to obtain an approximate estimate of the lowest temperature at which the radioactivity appeared in the case of calcium sulphate, a jet of steam was directed against the base of the electroscope. The temperature so obtained was sufficient to bring on the discharge, but the rate of leak was much smaller than when the electroscope was heated with the flame of a Bunsen burner.

Each of the salts given in Table I. was carefully tested for radioactivity at the temperature of the laboratory (about $18^{\circ} \mathrm{C}$.), both before being exposed to the cathode rays and after bombardment; but with the exception of potassium sulphate none of them produced a leak under these circumstances. With potassium sulphate, a small leak of positive electricity occurred if the test was made immediately after exposure to cathode rays. But this effect soon passed off, and was followed on the application of heat to the electroscope by the usual larger leak obtained with the other active salts.

None of the salts examined exhibited any radioactivity 
when heated without being previously exposed to cathode rays or to the spark-discharge.

As an example of the magnitude of the effects described in this paper, it may be stated that in one instance the radiation from a thin layer of active calcium sulphate, spread on the base of the electroscope over an area of twenty square centimetres, discharged from two to three electrostatic units of positive electricity.

\section{Impressed Radioactivity and Thermoluminescence.}

E. Wiedemann* has shown that a number of substances, when exposed to cathode rays or to the spark-discharge, acquire and possess for some time the power of becoming luminous when their temperature is raised to a point far below that at which they become luminous in their normal state. To this phenomenon he has given the name thermoluminescence.

Now the methods of exciting this phenomenon are precisely the same as those adopted in imparting radioactivity to the various salts just mentioned; and as the range of temperatures over which both phenomena appear is about the same, it seemed possible that some connexion might exist between the two effects.

To investigate this point each of the salts was carefully tested for thermolnminescence, and the results obtained are recorded in column III., Table I. A reference to this table will show that in the case of three salts only was the radioactivity accompanied by the phenomenon of thermoluminescence. In the case of the remaining salts, some exhibited thermolnminescence, but not radioactivity, while with others radioactivity was observed, but no visible thermoluminescence.

From these results it seemed clear that no connexion existed between the two phenomena; but in order to test the matter still further, some experiments were made with a number of Van't Hoff's $\dagger$ so-called solid solutions, which were known to exhibit a powerful thermoluminescence. From Table II., which contains a summary of the results, it will be seen that radioactivity was observed with but one solution, namely $\mathrm{CaSO}_{4}+2$ p.c. $\mathrm{MnSU}_{4}$. The radioactivity obtained in this case was practically of the same intensity as that obtained with the simple salt, calcium sulphate.

* Zeitschr. f. Electrochem. vol. ii. p. 150 (1895).

+ Zeitschrift f. phys. Chemie, vol. v. p. 322 (1890). 
TABLE II.

\begin{tabular}{|c|c|c|c|}
\hline Solid Solution. & $\begin{array}{c}\text { Gold leaf } \\
\text { positirely } \\
\text { charged. }\end{array}$ & $\begin{array}{c}\text { Gold leaf } \\
\text { negatively } \\
\text { charged. }\end{array}$ & $\begin{array}{l}\text { Thermo- } \\
\text { luminescence. }\end{array}$ \\
\hline $\mathrm{OaSO}_{4}+2$ p.c. $\mathrm{MnSO}_{4}$ & Leak. & No leak. & Intense green. \\
\hline $\mathrm{ZnSO}_{4}+1$ p.c. $\mathrm{MnSO}_{4}$ & No leak. & & Intense red. \\
\hline $\mathrm{MgSO}_{+}+1$ p.c. $\mathrm{MnSO}_{+}$ & & $"$ & Intense dark red. \\
\hline $\mathrm{CdSO}_{4}+1$ p.c. $\mathrm{MnSO}_{4}$ & $" \quad$, & " & Intense yellow. \\
\hline $\mathrm{CaFl}_{2}+2$ p.c. $\mathrm{MnFl}_{2}$ & " & " & Bright green. \\
\hline
\end{tabular}

Since, therefore, radioactivity was impressed on but one of the five solid solutions, while they all exhibited a very pow'erful thermoluminescenee, it seems obvious that no direct connexion exists between the two phenomena.

This conclusion is also confirmed by the fact that while a temperature of $100^{\circ} \mathrm{C}$., or even less, sufficed to exhibit radioactivity in connexion with most of the salts examined, a temperature considerably higher than this was found to be necessary to produce visible thermoluminescence. In fact, in a test made with the sulphates of strontium and barium the radioactivity had almost entirely disappeared before thermoluminescence became well-marked.

Moreover a difference exists in the intervals of time during which the excited salts retain the power to exhibit the two phenomena. As is well known, bodies exhibiting thermoluminescence retain this property for weeks, or even months, after exposure to cathode rays. On the other hand, the present investigation goes to show that salts rendered radioactive by cathode rays completely lose their activity in the course of one or, at most, two or three days.

\section{Character of the Radiation.}

An experiment was made to see whether the radioactivity could be detected when the electrostatic field of the gold leaf was screened off from the salt by means of a sheet of wire gauze placed above the salt, as shown by the dotted line in fig. 1. Little difference was observed when gauze with meshes 3 millimetres in width was used, but with ganze made from wires $1 \mathrm{~mm}$. in diameter, placed $1 \mathrm{~mm}$. apart, the leak from the measuring system was greatly diminished.

From the experiments made so far, there appear to be but 
Notations employed in Theories of Crystal-structure. 203 two obvious ways of explaining this peculiar rauiation. One of these is to regard the effect as due to ultra-violet light produced by heating the excited salt, this light acting on the negatively-charged salt and thereby causing a leak from its surface.

To test this view, an amalgamated zinc sphere, Z (fig.1), was attached to the lower end of the measuring system. With this arrangement, though the zinc sphere was within four millimetres of the radioactive salt, no indication of a discharge of negative electricity from the gold leaf was observed.

It seems scarcely possible that an ultra-violet radiation, capable of producing the effects observed, could be absorbed completely in passing through air at $15 \mathrm{mms}$. pressure for a distance of only four millimetres.

Probably the simpler view to take is that the salts on being heated emit a stream of negatively-charged particles or corpuscles which are drawn to the positively-charged yold leaf by the electrostatic field. and thus discharge it. If this view be correct, these negatively-charged particles must be sent out from the salt with exceedingly small velocities, otherwise we would expect the gold leaf, when initially unelectrified, to acquire at least a small negative charge.

The experiments described in this paper were conducted in the Cavendish Laboratory, and my sincere thanks are due to Professor Thomson for many valuable suggestions and much encouragement given throughout the investigation.

August 1st, 1901.

XXI. A Compurison of various Notations employed in "Theories of Crystal-structure," and a Revision of the 230 Groups of Movements. By Hanold Hilton, Magdalen College, Oxford ${ }^{*}$.

GINCE the determination of the possible groups of movements must hold an important position in any future theories of crystal structure; and since the mathematical theory of these groups has been practically brought to a completion; it seemed advisable to draw up tables comparing the different notations of the various workers on the subject, with the hope that at the same time a judgment might be formed on the correctness of the staiement that the number of groups of movements which are applicable to crystallography is 230 .

* Communicated by the Author. 